\title{
Social representations of imprisoned women on Acquired Immunodeficiency Syndrome
}

\author{
Representações sociais de mulheres em situação de cárcere sobre a Síndrome da \\ Imunodeficiência Adquirida
}

Tatyana Ataíde Melo de Pinho ${ }^{1}$, Antonia Oliveira Silva ${ }^{1}$, Cláudia Jeane Lopes Pimenta ${ }^{1}$, Maria Adelaide Silva Paredes Moreira ${ }^{1}$

Objective: to understand the social representations of imprisoned women on Acquired Immunodeficiency Syndrome. Methods: qualitative study conducted with 32 women imprisoned in a rehabilitation center. The Free Association of Words Test was used, with inductive stimuli such as "Human Immunodeficiency Virus" and "Acquired Immunodeficiency Syndrome". Data were processed by the EVOC software and analyzed in light of the Theory of Social Representations. Results: the elements of the central nucleus of the representation were prevention, fear, death, disease and anguish; the periphery revealed negative aspects regarding the contents. Conclusion: there has been a process of modification in the social representations on the Acquired Immunodeficiency Syndrome with the incorporation of new elements such as the prevention and the reduction of the feeling of imminent death.

Descriptors: Acquired Immunodeficiency Syndrome; Women; Prisoners; Nursing.

Objetivo: compreender as representações sociais de mulheres em situação de cárcere sobre a Síndrome da Imunodeficiência Adquirida. Métodos: estudo qualitativo, realizado com 32 mulheres sentenciadas em um centro de reabilitação. Utilizou-se o Teste de Associação de Livre de Palavras, tendo como estímulos indutores "Vírus da Imunodeficiência Humana" e "Síndrome da Imunodeficiência Adquirida". Dados processados pelo software EVOC e analisados à luz da Teoria das Representações Sociais. Resultados: os elementos do núcleo central da representação foram prevenção, medo, morte, doença e angústia; a periferia revelou facetas negativas quanto aos conteúdos. Conclusão: observou-se início de um processo de modificação nas representações sociais sobre a Síndrome da Imunodeficiência Adquirida, tendo-se a incorporação de novos elementos, como a prevenção e a diminuição do sentimento de morte iminente.

Descritores: Síndrome de Imunodeficiência Adquirida; Mulheres; Prisioneiros; Enfermagem.

${ }^{1}$ Universidade Federal da Paraíba. João Pessoa, PB, Brazil.

Corresponding author: Tatyana Ataíde Melo de Pinho

Rua Hercílio Alves de Sousa, 249, Bancários. CEP: 58051-290. João Pessoa, PB, Brazil. E-mail: tataide8@hotmail.com 


\section{Introduction}

Acquired Immunodeficiency Syndrome (AIDS) emerged in Brazil in 1982 as a mysterious and feared phenomenon, mainly due to its lethality and disfiguring body characteristics. Today, after more than three decades, it still represents a global and dynamic phenomenon, highlighted among the infectious diseases that cause more deaths among women ${ }^{(1)}$.

The epidemic has presented epidemiological and social changes over the last few years. It has ceased to be a metropolitan disease that originated in the upper classes, which affected people from the artistic-cultural milieu and was restricted to risk groups (homosexuals, drug users and sex workers) to be considered an internal disease, with a popular origin, affecting any person and spreading to socially considered non-vulnerable individuals, such as heterosexuals, monogamous women, the elderly and children ${ }^{(2)}$.

It is noteworthy that women have become increasingly vulnerable to this infection, accounting for half of those living with AIDS worldwide ${ }^{(3)}$. In addition, the steady increase of the female imprisoned population, reaching more than 10.35 million people in prisons around the world ${ }^{(3)}$, has potentiated the vulnerability of contamination by the Human Immunodeficiency Virus (HIV).

The relevance expressed in these data was extensively discussed in the Melbourne Declaration, which signaled changes and concerns in the outline of this infection, revealing the emergence of new vulnerable groups, among which are the women deprived of their liberty ${ }^{(3-5)}$. In this sense, despite the efforts of the Brazilian Ministry of Health, HIV/AIDS prevention, diagnosis and care actions in the Brazilian prison system are still not in accordance with the care practice provided to other population groups, which favors the perpetuation of the threatening and destructive image of the infection ${ }^{(6)}$.

The strategies developed for women deprived of liberty must be differentiated, given the need for greater assistance aimed at promoting the health of this population, due to the greater vulnerability of the prison environment, characterized by violence, marginalization and oppression ${ }^{(7-8)}$.

Given this scenario, knowledge about HIV and AIDS is referred to in the literature as an important tool for adopting self-care practices ${ }^{(6,9)}$, favoring prevention and reduction of risk behavior ${ }^{(10)}$, above all, in the prison population, whose deprivation of liberty reinforces the precariousness and fragility of the guarantee of sexual rights, due to the bureaucratic and structural limitations existing in the prison establishment $^{(7-8)}$.

The evidence of gaps in the knowledge of women deprived of their freedom in relation to AIDS encourages research that addresses dimensions related to the association between infection and imprisonment. Among the many dimensions, there is highlight to the identification of social representations about AIDS $^{(6)}$, the guarantee of sexual and reproductive rights of these women ${ }^{(8)}$, the analysis of individual, sexual, social and contextual conditions that contribute to the adoption of HIV risk behaviors ${ }^{(9-10)}$, among other aspects, both nationally and internationally.

The number of women deprived of their liberty living with HIV has increased over the years, thus, there is a need for investments in sociocultural diagnoses of HIV infection and in prevention and care actions applied in a comprehensive, multisectoral and integrated way, with the purpose of meeting the specific needs of this population ${ }^{(6)}$. In this sense, it is essential to investigate AIDS from the perspective of these women, seeking to understand the ways in which the infection is represented in the prison environment.

Through this context, some questions have arisen: what are the social representations about aids built by imprisoned women? What elements are present in the central and peripheral systems of these representations?

Therefore, the present study aimed to understand the social representations of imprisoned women on Acquired Immunodeficiency Syndrome. 


\section{Methods}

This is a qualitative study carried out in a female penitentiary, in the city of João Pessoa, Paraíba, Brazil, between October and November 2014. The selection of the participants occurred in a non-probabilistic way, by convenience, using as an inclusion criterion the serving of sentence in a closed system, corresponding to 32 women. Women who were in the process of progression from closed to semi-open regime were excluded from the study.

For data collection, a semi-structured questionnaire was applied, addressing sociodemographic variables and issues or images inherent to the field of representation, as well as knowledge or information and attitudes of women in deprivation of liberty regarding HIV and AIDS. The speeches of each subject were identified by the abbreviation "Sub.", followed by an ordinal number corresponding to the interview order.

The analysis of the speeches was based on the Theory of Social Representations, which seeks to identify the problem from the perspective of the individual, constituting a theoretical support used to implement and actualize health practices ${ }^{(11)}$. This framework allows the understanding of the concepts or phenomena that subjects associate with the disease, which are responsible for the way empirical reality abstracts them and gives them meaning ${ }^{(12)}$.

The Free Association of Words Test was also used, which consists of a type of investigation that is structured from the evocation of answers given by the participants through one or more inductive stimuli, allowing to highlight the semantic universes related to a given object ${ }^{(13)}$. The investigated women were asked to evoke five words that came to mind as they heard the inducing stimuli "Human Immunodeficiency Virus" and "Acquired Immune Deficiency Syndrome". They were then asked to choose the evocation perceived as the most important ${ }^{(12,14)}$.

The data were organized in a specific database to be processed in EVOC software, based on the Cen- tral Nucleus Theory, characterized as one of the three approaches of Theory of Social Representations, not limited to the explanatory scope of the process of formation of representations, but with an emphasis on the cognitive-structural dimension ${ }^{(13)}$. This software provides the organization of the words produced, respecting the hierarchy presented by the frequencies (collective dimension) and mean order of evocation, which concerns the individual dimension, allowing the accomplishment of statistical calculations and the construction of matrices of competitions ${ }^{(12)}$.

In the frame of four houses, the upper left quadrant, called the probable central nucleus, is formed by the words that presented the highest frequency and were more readily evoked, constituting the most stable and permanent part of the representation. In this case, the content is connected to the collective memory of the group, giving meaning to the representation. The lower left quadrant, called the contrast zone, is formed by the words that obtained lower frequencies and lower average order of evocation, demonstrating variations of centrality of representation for specific groups. The words located in this quadrant are the intermediate elements, which can approach the central nucleus or the peripheral elements ${ }^{(12)}$.

The upper right quadrant, called the first periphery, contains words that present higher frequency and higher average order of evocation. The lower right quadrant, called the second periphery, consists of words of low frequency and less readiness to evocation, which form the peripheral elements of representation. In this quadrant, there are less frequent and less important cognitions to determine the meaning of representation, but with more relation to social insertion and more sensitive to the subjects' immediate practices. These peripheral zones are unstable, allowing variations of representations, as they express the representational elements associated with daily reality and social practices ${ }^{(12)}$.

The representations are organized around the central nucleus, which determines the meaning and the internal organization of the representation, having 
the functions of generating and organizing ${ }^{(12)}$. The first function presents elements responsible for creating or transforming the content of the elements of the peripheral system; and the second function seeks to unify and stabilize representation. In this way, a change of the elements that make up the central nucleus can trigger a transformation of the representation of the studied object. In addition to these two functions, there are still two dimensions related to the central nucleus: the functional, linked to the accomplishment of tasks, and the normative, which involves social, affective and ideological dimensions. The peripheral system presents a functional dimension, making it possible to represent the reality of the moment due to the flexibility that regulates and adapts the central system to a concrete situation ${ }^{(12)}$.

The study complied with the formal requirements contained in the national and international regulatory standards for research involving human beings.

\section{Results}

Regarding the profile of the participants, there was a prevalence of $75.0 \%$ in the age group between 20 and 30 years old, single (50.0\%), with up to eight years of study (84.4\%) and evangelicals (56.2\%). Of the women interviewed, $53.1 \%$ were serving their sentences for less than a year, $87.5 \%$ declared themselves to be heterosexual, only $3.1 \%$ had received an intimate visit, and $90.6 \%$ had not used a condom.

The results showed 128 evocations with 41 different words. The mean frequency was calculated at five and the rang was two and a half. The most frequent elements were prevention, death, fear, treatment, disease, depression, care, distress and isolation. The lowest frequencies were related to cure, sentence, condom, prejudice, contempt, pain, poor and transmission.

The first quadrant constituted the probable central nucleus represented by the imprisoned wo- men, such as anguish, disease, fear, death and prevention. With regard to the intermediate elements, located in the lower left quadrant, these were: prejudice, sentence and cure; and, in the upper right quadrant, the elements: care, depression, isolation and treatment, indicating the range of meanings attributed to AIDS and that approach both to the centrality and to the periphery.

In the lower right quadrant, called the second periphery or peripheral system, the following terms were found: contempt, pain, condom, poor and transmission, which translated feelings and emotions experienced in the daily life of these women, expressing, in most cases, negative aspects related to suffering against the representational context.

Prevention, anguish, disease, fear, and death were the probable central nucleus. The emotional factor is determined by the impending death linked to the disease. The element prevention converged to evocations of care and treatment. Fear appeared to be associated with the fear of falling ill, especially in prison, due to multiple partners, sharing of objects such as nail pliers and sewing needles; there was also the fear of exclusion, of loneliness. Therefore, fear was linked not only to the risk of death, but also to a social stigma.

Negative sentiment domains were defined by the terms death, fear, disease and anguish; and a functional dimension linked to more operational processes, showing proximity to the social object investigated. This element consists of a set of practices and behaviors, such as the use of condoms, the non-sharing of supposedly personal objects (pliers, needles, cutlery, sandpaper, dish, absorbent) and abstinence from relationships with suspects.

Thus, the prevention evoked by women seemed to point to a representation of AIDS with meaning generation and internal organization around the need for safe sex, dependent on the use of condoms and the non-sharing of personal objects, but with the disclaimer that trust in the other was still a reason for 
not adopting these practices. You can only get AIDS through sex without a condom, nail plier, blood, needle, razor, cutlery, glass ... Even if you have a husband, most of them have a woman in here and do not protect themselves during sex. They do not allow condoms to get in here ... I used it at the beginning, now that I know him, I no longer need to use a condom ... (Sub. 05). I'm married but I do not use a condom. I trust him, I'm already used to him, so I do not use it. The ones who have a naughty husband have to use a condom... (Sub. 15).

In the intermediate nucleus, the evocations related to the psychosocial contents were grouped, especially with prejudice and the relation of it with depression, isolation, the sentence, cure, care and the treatment. ...Most people discriminate against people with AIDS ... Nobody wants to be close to those who have AIDS; they feel disgusted by the sick person, have these attitudes of withdrawal because of the fear of getting the disease... (Sub. 15).

Around the central nucleus, we found the periphery of the representation of AIDS, which focused mainly on negative feelings, which emerged from the process of thinking about the disease and its social consequences. The socio-cognitive contents of a psycho-sociological approach denoted a negative view of the disease, associated with poor, transmissible, pain, attitudes of contempt and isolation.

The elements that formed the periphery encompassed evocations whose contents linked to suffering were anchored in physical, biological and psychological dimensions. Only those who have AIDS can avoid transmission to other people. So, it is very difficult here in prison, because we live with a lot of people here and we do not know who has the disease. People with AIDS should have a special place, not to join with normal people. This is the only way to prevent and avoid transmission ... (Sub.01). Many people live in my cell and if anyone has AIDS, all the others will get it, so they should stay in a separate cell. I only sit in places when the warmth of the place disappears, I always expect it to cool in order to prevent AIDS. We can also get it by drinking water in the same glass, wearing the same clothes, in a hug, a kiss, in everything. We can know if a person has AIDS; just by looking at them, it is clear to see. The person becomes thin, disabled, with no hair... (Sub.25).

\section{Discussion}

To interpret the results, we should consider the limitations related to the method used, due to the subjectivity related to the qualitative approach.

In the perspective of social representations, cognitions with functional dimensions were observed, associating HIV and AIDS with prevention, condoms, transmission and physical pain, as well as with normative dimensions related to death, fear, anguish, pain, social, contempt due to prejudice, mainly for fear of contagion ${ }^{(14)}$.

The results of this study evidenced a process of modification in the social representations of AIDS, incorporating elements related to prevention, care and treatment of the disease, which represents evolution in the way the epidemic has been understood, although there are frequent crystallized positions on the infection and its association with death and suffering ${ }^{(6)}$.

This finding is relevant because it points to a representational change in the central system, as it evidences an attempt to overcome the representation of immediate death by the syndrome, seeking strategies to cope with its condition in an attempt to adapt to the current context of life and health ${ }^{(15)}$. Thus, the representation of AIDS brings to the fore the idea of prevention, however, there are still practices and risk behaviors, such as not using condoms in a relationship based on trust and strong bonds of affection ${ }^{(16)}$. Also, the non-sharing of objects and the need to know the partner with whom they relate are the most used prevention strategies used by the female prison population $^{(6)}$

Although the imprisoned women have attached to forms of prevention to represent AIDS, contents such as fear, death and anguish are still rooted in collective emotions, being a product of social representations marked at the beginning of the epidemic, but still circulating in the scientific means, in mass communication, in social media and in popular thought, generating prejudice, stigma and negative represen- 
tations ${ }^{(17-19)}$. Moreover, such representations are also anchored in psychosocial dimensions, such as the fear of rejection and contempt that adds to the suffering due to the possibility of prejudice to which these women are exposed ${ }^{(2,19-20)}$. Therefore, they often prefer to hide the disease as a form of social resistance not to be discriminated against it.

In this sense, one can perceive the presence of negative connotation that is tied to a distorted representation, propagated and replicated over time, mainly by the media. The origin of this concept lies in the lack of scientific knowledge about the disease at the beginning of the epidemic, alluding to the references that associated it with certain groups of the population, with attitudes and practices not accepted by society. This set of factors caused negative information to be conveyed by the mass media, reflecting a stereotype of pejorative connotation in relation to the carriers and the possible risk groups, which generated fear in the population and increased prejudice ${ }^{(19)}$.

In the case of women deprived of their liberty, such representations are directly and indirectly influenced by the presence of barriers generated by the prison system itself, such as illicit drug use, deficiency of the social support system, high incidence of mental problems and presence of a history of sexual work and physical, sexual, psychological and emotional abuse by intimate partners ${ }^{(6)}$. Associated with this, there are obstacles related to the liberation and resocialization of these women in the community, such as increased sexual risk, increased use of illicit substances and high rates of recidivism ${ }^{(9)}$.

Even with the advances in treatments and the increase in the life expectancy of people living with AIDS, the physical and social suffering inherent to the disease has not changed, that is, intolerance, fear, discrimination and prejudice are still present in the current society, intensified by idealizations on the infection, which are still frequent in the imaginary of a large part of the population ${ }^{(2)}$.

Social stigma affects the quality of life of women, especially in situations of deprivation of liberty.
Therefore, it is necessary to rethink ways of combating these aspects of the repercussion of the disease that are present in the social representations of AIDS, which are responsible for disseminating frightening meanings in relation to the epidemic, negatively influencing the implementation of actions and strategies for preventing and controlling this injury ${ }^{(15-16)}$.

The participants of the present study presented scientifically proven knowledge about the forms of HIV transmission, such as sexual intercourse without the use of condoms, contaminated blood and contact with sharps, characterizing the reified universe of representations. On the other hand, they also pointed out elements revealing prejudice, listing items such as cutlery, glass, "seat warmth", which demonstrates the consensual character of representations.

Similar data were evidenced by a study carried out with 174 imprisoned women, which revealed the existence of social representations related to the beginning of the epidemic in the country, with the presence of misinformation about the disease, which supports discriminatory and prejudiced attitudes ${ }^{(6)}$. Although they recognize the importance of prevention, women still perceive the infection as an evil that relates to the other, not perceiving themselves at risk. This problem becomes more visible when they maintain stable relationships, with confidence between the partners, since many expressed the lack of the need to use the condom.

It is important to highlight that the "monogamous relationship" was considered by the participants as a form of prevention. This brings up the issues of trust and fidelity, since, because they believe they are in a stable relationship, they are not at risk of acquiring the infection. In addition, many women are uncomfortable in suggesting condom use for their partner in long-term relationships, as their use is still tied to the idea of betrayal, mistrust and promiscuity ${ }^{(19)}$.

In the case of sexual intercourse occurring within the prison environment, there are other factors increasing the risk of HIV transmission, such as the 
prison condition itself, the physical inadequacy of the internal and external spaces, the high population density, the precarious hygiene, health and nutrition and the non-availability of condoms ${ }^{(17)}$.

A study of 1,369 men and women incarcerated in New York City identified that a significant proportion of the prisoners were sexually active and that most of them were not in the marital visitation program. This refers to the presence of sexual relationships within the prison environment, which occurred without the use of condoms, since they were not available to the prison population ${ }^{(10)}$.

Still today, people perceive HIV infection as if it was due to risky behavior, failing to consider that the modes of transmission of a disease often have more social than individual reasons. Therefore, these issues are not solved by seeking to blame people for actions taken or by labeling individuals as models of behavior, but by understanding the motives that condition people and groups to be more vulnerable to HIV infection ${ }^{(9)}$.

\section{Conclusion}

This study evidenced the beginning of a process of modification in the social representations of AIDS, incorporating new elements, such as prevention and reduction of feeling of imminent death. However, the disease still presents a threatening and destructive image, which increases prejudice and stigmatization of the carriers.

\section{Collaborations}

Pinho TAM contributed to the design conception and design, analysis and interpretation of data. Pimenta CJL collaborated with the writing of the article. Silva AO and Moreira MASP contributed to the critical review of the intellectual content and final approval of the version to be published.

\section{References}

1. Lima TC, Freitas MIP. Caracterização de população com 50 anos ou mais atendida em serviço de referência em HIV/AIDS. Rev Ciênc Méd [Internet]. 2013 [citado 2017 nov. 13]; 22(2):77-86. Disponível em: http://periodicos.puc-campinas. edu.br/seer/index.php/cienciasmedicas/article/ view/2129/1779

2. Oliveira DC. Construction and transformation of social representations of aids and implications for health care. Rev Latino-Am Enfermagem. 2013; 21(esp):276-86. doi: http://dx.doi.org/10.1590/ S0104-11692013000700034

3. Joint United Nations Programme on HIV/AIDS (UNAIDS). Ending AIDS: Progress Towards the 90 - 90 - 90 Targets [Internet]. 2017 [cited 2017 Nov. 13]. Available from: http://www.unaids.org/ sites/default/files/media_asset/Global_AIDS_ update_2017_en.pdf

4. Walmsley R. World female imprisonment list: women and girls in penal institutions, including pre-trial detainees/remand prisioners [Internet]. 2017 [cited 2017 Nov. 13]. Available from: http:// www.prisonstudies.org/sites/default/files/ resources/downloads/world_female_prison_4th_ edn_v4_web.pdf

5. Seffner F, Parker R. The waste of experience and precariousness of life: contemporary political moment of the Brazilian response to aids. Interface. 2016; 20(57):293-304. doi: http:// dx.doi.org/10.1590/1807-57622015.0459

6. Trigueiro DRSG, Almeida SA, Monroe AA, Costa GPO, Bezerra VP, Nogueira JA. AIDS and jail: social representations of women in freedom deprivation situacions. Rev Esc Enferm USP. 2016; 50(4):55461.doi:http://dx.doi.org/10.1590/S0080623420160000500003

7. Lopes TC, Pinheiro R. Trajetórias de mulheres privadas de liberdade: práticas de cuidado no reconhecimento do direito à saúde do Centro de Referência de Gestantes de Minas Gerais. Physis. 2016; 26(4):1193-212. doi: http://dx.doi. org/10.1590/s0103-73312016000400007 
8. Costa LHR, Alves, JP, Fonseca CEP, Costa FM, Fonseca FF. Gender in the context of sexual and reproductive rights of women deprived of liberty. Enferm Glob [Internet]. 2016 [cited 2017 Nov. 13]; 43:151-63. Available from: http://revistas. um.es/eglobal/article/view/207141/194671

9. Fogel CI, Gelaude DJ, Carry M, Herbst JH, Parker S, Scheyette A et al. Context of risk for HIV and sexually transmitted infections among incarcerated women in the south: individual, interpersonal, and societal factors. Women Health. 2014; 54(8):694-711. doi: http://dx.doi.org/10.1 080/03630242.2014.932888

10. Rowell-Cunsolo TL, Szeto B, Sampong SA, Larson EL. Predictors of sexual behavior among men and women in New York City area prisons. Cult Health Sex. 2016; 8:1-14. doi: http://dx.doi.org/10.1080 /13691058.2016.1188420

11. Moscovici F. Representações sociais: investigações em psicologia social. Petrópolis: Vozes; 2012.

12. Moscovici F. O fenômeno das representações sociais. In: Moscovici S. Representações sociais. Petrópolis: Vozes; 2003. p.29-109.

13. Rosa AS. A rede associativa: uma técnica para captar a estrutura, os conteúdos, e os índices de polaridade, neutralidade e estereotipia dos campos semânticos relacionados com as representações sociais. In: Moreira ASP, Camargo BV, Jesuíno JC, Nóbrega SM, editoras. Perspectivas teórico-metodológicas em representações sociais. João Pessoa: Universitária UFPB; 2005. p. 61-127.

14. Bardin L. Análise de conteúdo. São Paulo: Edições 70; 2011.
15. Hipolito RL, Oliveira DC, Gomes AMT. Conteúdos simbólicos da qualidade e vida gerados por pessoas que vivem com HIV/aids. Atas Cia [Internet]. 2015 [citado 2017 nov 13]; 484-6. Disponível em: http://proceedings.ciaiq.org/ index.php/ciaiq2015/article/viewFile/111/107

16. Pimenta CJL, Costa IP, Farias MCAD, Costa KNFM, Pereira TLB, Leite ES, et al. HIV/AIDS and seniors: knowledge of elderly about the disease. Int Arc Med. 2016; 9(20):1-7. doi: http://dx.doi. org/10.3823/1891

17. Pinheiro PNC, Freitas CM, Scopacasa LF, Silva KL, Gubert FA, Luna IT. Adolescent with Human Immunodeficiency Virus - understanding family beliefs and values. Rev Rene. 2017; 18(4):50714. doi: http://dx.doi.org/10.15253/21756783.2017000400012

18. Faria JO, Silva GA. Nursing diagnoses in persons with HIV/aids: an approach based on Horta's conceptual model. Rev Rene [Internet]. 2013 [cited 2017 Nov. 13]; 14(2):290-300. Available from:http://www.revistarene.ufc.br/revista/ index.php/revista/article/view/821

19. Pimenta CJL, Costa IP, Leite ES, Farias MCAD, Barbosa TL, Maciel EJS, et al. Understanding of the Elderly Attached to the Family Health Strategy about the HIV/AIDS Infection. Int Arc Med. 2015; 8(241):1-7. doi: http://dx.doi.org/10.3823/1840

20. Strauss M, Rhodes B, George G. A qualitative analysis of the barriers and facilitators of HIV counseling and testing perceived by adolescents in South Africa. BMC Health Serv Res. 2015; 15:250. doi: http://doi.org/10.1186/s12913-015-0922-0 